$\Phi=$

\title{
Impact of the foraging activity of Apis mellifera adansonii Latreille (Hymenoptera: Apidae) and Bradyrhizobium fertilizer on pollination and yield components of Glycine max L. (Fabaceae) in the field
}

\author{
Stephanie BeaudelaineKengni ${ }^{1,2}$ *, Fernand-Nestor Tchuenguem Fohouo ${ }^{2}$, Albert Ngakou ${ }^{2}$ \\ ${ }^{I}$ Department of Biological Science, Faculty of Science, University of Maroua, P.O. Box 55 Maroua, Cameroon \\ ${ }^{2}$ Department of Biological Science, Faculty of Science, University of Ngaoundéré, P.O. Box 454 Ngaoundere, Cameroon \\ *Corresponding authorE-mail:kbeaudelaine@yahoo.fr
}

\begin{abstract}
To determine the impact of Apis mellifera adansonii and Bradyrhizobium on pod and seed yields of Glycine max, field trials were carried out during 2012 and 2013 cropping seasons. Hence, 120 to 25658 flowers were labeled each year and divided into five treatments, differentiated according to whether plots were inoculated with Bradyrhizobium or not, or plants were protected from insects activities or not and the last treatment with flowers isolated then opened only to A. m. adansonii. The effects of Bradyrhizobium on nodulation, plant biomass and seed yield, as well as the foraging behavior of $A . m$. adansonii on flowers, the number of seeds per pod and the normal seeds' rate were evaluated. Results indicate that Bradyrhizobium significantly increased the number of flowers $(\mathrm{P}<0.001)$, root nodules $(\mathrm{P}<0.0001)$, plant biomass $(\mathrm{P}<0.0001)$, pod and seeds yields in inoculated plots. A. $m$. adansonii foraged on $G$. max flowers from 09.00 a.m. to 16.00 p.m. and throughout the whole blooming period. This insect intensely harvested only nectar. By comparing the yields of unprotected flowers to those of flowers isolated then opened to A. m. adansonii, 35.85\% increase fructification index, and $73.09 \%$ increase in the number of seeds per pod due to this bee were recorded. The synergistic activity of insects and Bradyrhizobium increased the number of seeds per pod by $32.16 \%$ and the percentage of normal seeds by $32.87 \%$. Our results reveal that inoculation of soybean plant at sowing with Bradyrhizobium and installation of hives close to the field could be recommended for a sustainable pods and seed yield improvement of this crop.
\end{abstract}

Keywords: Apis mellifera adansonii; Bradyrhizobium; Foraging activity; Glycine max; Yields.

\section{Introduction}

Soybean [Glycine $\max (\mathrm{L}$.$) Merrill] is the world's leading source$ of oil and protein (Ikeogu\&Nwofia 2013). It has the highest protein content of all crops legume (38-40\%) and is second only to groundnut in terms of oil content among food legumes (Tien et al. 2002, Alghamdi 2004, Ikeogu\&Nwofia 2013). The plant is an annual, herbaceous, erected crop, and can reach a height of $1.5 \mathrm{~m}$. Soybean cultivars have been reported to be indeterminate, determinate and semi-determinate in growth habit (Gallais\&Bannerot 1992). The first leaves are simple, opposite and swallowed, while the following ones are trifoliate and alternate (Hymowitz\& Harlan 1983). Pods are straight or slightly curved, with a length of 2-7 $\mathrm{cm}$; the seed is generally oval, but may vary depending on the cultivar, almost spherical, elongated or flattened (Hymowitz\& Harlan 1983). Flowers are grouped by two 2-8 on a short racemes inserted on the stem axile sheets and are purple or white (Boyeldieu 1991). Each flower has a tubular calyx of 5 sepals, a corolla of 5 petals, a single carpel and 10 stamens, 9 of which are welded while the tenth is free (Hymowitz\&Harlan 1983). Each flowers produce nectar and pollen which attract insects (Milfont et al. 2013). Soybean is grown primarily for its seeds, which have many uses in the food and industrial sectors (Diers et al. 1992). Current- ly the production of G. max in Cameroon is low whereas the demand for seeds is high (MINADER 2012). Therefore, it is important to investigate on the possibilities of increasing the production of this valuable plant in the country. This can be achieved if G. $\max$ flowering insects in each region are well-known and exploited (Milfont et al. 2013) or by introducing microbial inoculants, which can have been applied to legume crops for over 120 years as bio-fertilizers (Ormeno-orrillo et al. 2012), which have a direct beneficial effect on the host plant (Denison \& Kiers 2004, Ngakou et al. 2009, Kengni et al. 2015).

Unfortunately no research has been reported on the relationships between G. max, inoculation with Bradyrhizobium and its anthophilous insects in Cameroon. In Ngaoundere A. m. adansonii visit flowers of $G$. $\max$ (unpublished data), and this study is carried out to assess the effects of foraging activities of A. m. adansonii on yields of G. max. In Maroua, A. m. adansonii has recently been reported to visit $G$. $\max$ flowers by Tchuenguem\&Dounia (2014) resulting in a significant increment in fruiting rate, number of seeds and percentage of normal seeds respectively by $14.14 \%$, $36.95 \%$ and $32.61 \%$.

The main objective of this research was to gather more data on the relationships between G. max, Bradyrhizobium and flowers visiting insects for the optimal management of pollination services. The registration of the activity of $A$. $m$. adansonii on $G$. max 
flowers, the evaluation of the impact of visiting insects on pollination, pods and seeds yields of this Fabaceae, the estimation of pollination efficiency of $A$. m. adansonii on this plant, the estimation of the impact of Bradyrhizobium on soybean and the evaluation of the impact of the cumulative action of Bradyrhizobium and flowers visiting insects especially $A$. $m$. adansonii are discussed.

\section{Material and methods}

\subsection{Study site, experimental plot and biological material}

The experimental was carried out in the field from march to september, in 2012 and 2013 at Beka-Hossere $\left(07^{\circ} 31.547^{\prime} \mathrm{N}\right.$ $13^{\circ} 54.659^{\prime} \mathrm{E}, 1117 \mathrm{~m}$ above sea level) in Ngaoundéré, Adamaoua region of Cameroon. This region belongs to the high-altitude guinean savannah agro-ecological zone (Tchuenguem et al. 2007). The climate is characterized by a distinct rainy (april to october) and dry (november to march) seasons, with an annual rainfall of about $1500 \mathrm{~mm}$. The mean annual temperature is $22^{\circ} \mathrm{C}$, while the mean annual relative humidity is $70 \%$ (Tchuenguem et al. 2007) The animal material was represented by insects naturally present in the environment, many colonies of Apis mellifera adansonii Latreille (Hymenoptera: Apidae) located about $3 \mathrm{~km}$ in diameter around the experimental site and a hive of Apis mellifera adansonii installed at $1 \mathrm{~m}$ of the experimental site in 2013.

The vegetation was represented by crops, ornamental plants and native plants of savannah and gallery forest. The vegetation near G. max field had various unmanaged and cultivated species. Microbial inoculum of the genus Bradyrhizobium was produced at IRAD (The Institute of Research for Agricultural Development) Wakwa Ngaoundéré, while G. $\max$ seeds were from MaïscamNgaoundere Agro-industry (life cycle of 155 to 160 days).

\subsection{Sowing and weeding}

On may 5, 2012 and may 12, 2013, experimental plot was cleaned and divided into 18 subplots, each measuring $3 \mathrm{~m}^{2}$. Nine subplots were inoculated and nine uninoculated. Three seeds were sown in 3 lines per subplot, each of which had 12 holes per line. Holes were separated $25 \mathrm{~cm}$ from each other, while lines were $30 \mathrm{~cm}$ apart. Soybean seeds were inoculated as described by Ngakou et al. (2007). Weeding was performed manually as necessary to maintain plots weed-free.

\subsection{Determination of the reproduction system of Gly- cine $\max$}

On july 22, 2012, six subplots carrying 216 plants with 29254 flowers at the bud stage were labeled. Three subplots carrying 108 plants with 14247 flowers were left open to be pollinated (treatment 1) (Figure 1) and three others carrying 15007 flowers were protected with gauze mesh to prevent insect or other pollinating animals visits (treatment 2) (Figure 2). On july 25, 2013, the experiment was repeated. For treatment 3, four subplots carrying 108 plants with 20352 flowers and for treatment 4 four subplots carrying 108 plants with 18867 flowers.

Twenty days after shading of the last flower, the number of pods was assessed in each treatment.

The podding index $(\mathrm{Pi})$ was then calculated as described by Tchuenguem et al. (2004): $\mathrm{Pi}=\mathrm{F} 2 / \mathrm{F} 1$, where $\mathrm{F} 2$ is the number of pods formed and $\mathrm{F} 1$ the number of viable flowers initially set. The allogamy rate (Alr) from which derives the autogamy rate (Atr) was expressed as the difference in podding indexes between treatment X (unprotected flowers) and treatment Y (bagged flowers) as follows (Demarly, 1977): Alr $=[(\mathrm{PiX}-\mathrm{PiY}) / \mathrm{PiX}] * 100$, Where $\mathrm{PiX}$ and $\mathrm{PiY}$ are respectively the podding average indexes of treatments $\mathrm{X}$ and $\mathrm{Y}$. Atr $=100-$ Alr.

\subsection{Assessment of the influence of inoculation on nodu- lation and biomass of Glycine max}

For each subplot, 18 plants for each treatment a (uninoculated subplot) and b (inoculated subplot) were labeled. Then nodules per plant were harvested at 60 days after planting (DAP), counted, sun dried, stored in envelopes, and weighed. Plants were dried in an oven at $72^{\circ} \mathrm{C}$ for 12 hours and weighed (Ngakou 2007). Biomass and nodulation were evaluated on the same 36 individual plants of treatments $\mathrm{a}$ and $\mathrm{b}$.

\subsection{Estimation of the frequency of Apis mellifera adan- sonii on Glycine max flowers}

The frequency of A. m. adansonii on G. max flowers was determined based on observations on treatments 1 and 3, every day, from july $16^{\text {th }}$ to august $16^{\text {th }} 2012$ and from july $26^{\text {th }}$, to august $25^{\text {th }}$ 2013, during four daily time frames: $09.00-10.00$ a.m., $11.00-$ 12.00 a.m., 13.00 - 14.00 p.m. and 15.00 - 16.00 p.m. Flowers were completely opened at 06.00 a.m. and closed before 06.00 p.m., but insects activity started at 9.00 a.m and stopped at 04.00 p.m.

By observing labeled flowers of treatments 1 and 3, all insect visits were recorded. Specimens of all insect taxa ( 3 to 5 per species) were caught with an insect net on flowers of unlabeled subplots. These specimens were conserved in $70 \%$ ethanol for subsequent taxonomy determination. All insects encountered on flowers were registered, and the cumulated results expressed in number of visits to determine the relative frequency of $A . m$. adansonii in the anthophilous entomofauna of G. max. In addition to the determination of the floral insects' frequency, direct observations of the foraging activity on flowers were made on insect pollinators in the experimental field. Nectar harvested by A. m. adansonii during each floral visit was registered based on its foraging behavior. Nectar foragers were observed extending their proboscis to the base of the corolla. Every sampling date, the number of opened flowers was counted, while the duration of the individual flower visits were recorded (using a stopwatch) at least three times: 10.00 - 11.00 a.m., 12.00 a.m. -13.00 p.m. and 14.00 a.m. -15 p.m.

Moreover, the number of pollinating visits (the bee came into contact with the stigma: Tchuenguem 2005), the abundance of foragers (highest number of individuals foraging simultaneously on a flower or on 1000 flowers: Tchuenguem et al. 2004) and the foraging speed referring to the number of flowers visited by a bee per minute (Jacob-Remacle 1989) were measured. Abundance per flower was recorded following the direct counting, on the same dates and daily periods as for the registration of the duration of visits. According to Tchuenguem (2005), the foraging speed could be calculated by this formula: $\mathrm{Vb}=(\mathrm{Fi} / \mathrm{di}) * 60$, where di is the time (sec) given by a stopwatch, and $\mathrm{Fi}$, the number of flowers visited during di. The disruption of the activity of foragers by competitors or predators and the attractiveness exerted by other plant species around experimental plot on A. m. adansonii was assessed.

During each observation date, temperature and relative humidity were registered after every 30 minutes using a mobile thermohygrometer. 


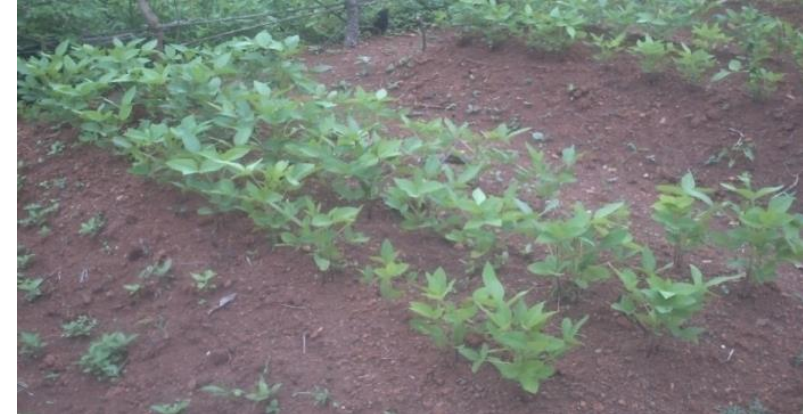

Fig. 1: Glycine max subplot showing unprotected plants.

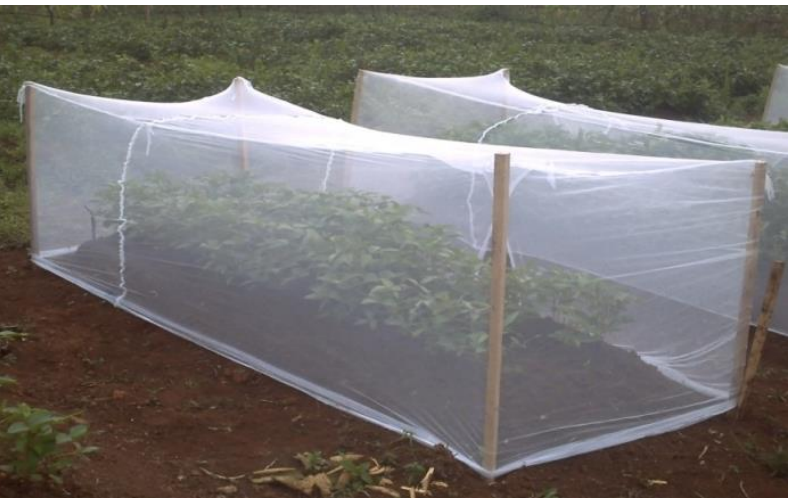

Fig. 2: Glycine max subplot showing isolated plants.

\subsection{Assessment of the cumulative effects of insects and Bradyrhizobium on Glycine max yields}

This evaluation was based on the impact of both Bradyrhizobium and insects on G. max yield. The comparison of yields (fruiting rate, mean number of seed per pod and percentage of norma seeds) of treatment 7 and 8 with those of treatments 2 and 4 were assessed. The contribution of cumulative action of insects and Bradyhizobium on G. max fruiting rate, mean number of seeds per pod and the percentage of normal seeds was calculated by the Frx above formula.

\subsection{Data analysis techniques}

Data were subjected to descriptive statistics, student's t-test for the comparison of means of the two samples, correlation coefficient (r) for the study of the association between two variables, chisquare $\left(\chi^{2}\right)$ for the comparison of two percentages and ANOVA for the comparison of means of more than two samples. SPPSS statistical program was used to assess the correlation between the pod and yield parameters.

\section{Results}

\subsection{Reproduction system of Glycine max}

According to table 1, allogamy, rate was $21.43 \%$ and $29.07 \%$ respectively in 2012 and 2013; whereas the autogamous rate was
$78.57 \%$ and $79.93 \%$ respectively in 2012 and 2013. Glycine max used in our experiments, had a mixed reproduction system antogamous-allogamous, with the predominance of autogamy. Our results line with those of Tchuenguem\&Dounia, 2014, who reported the predominance of autogamy $(94.01 \%)$ over allogamy (5.98\%) on G. max in Maroua. Therefore, it is suggested that the mating system of $G$. max may not vary from one agroecological zone to another.

Table 1: Reproduction system of Glycine max in years 2012 and 2013

\begin{tabular}{lll}
\hline Years & Autogamous rate (\%) & Allogamy rate (\%) \\
\hline 2012 & 78.57 & 21.43 \\
2013 & 79.93 & 29.07 \\
Mean (2012/2013) & 79.25 & 25.25 \\
\hline
\end{tabular}

\subsection{Effect of Bradyrhizobium on numbers of flowers, nodulation and biomass of Glycine max}

The number and dry weight of nodules per plant, the numbers of flowers per subplot and plant biomass were assessed on G. max (Table 2) in 2012 and 2013. Plants inoculated at sowing produced a significantly higher numbers of nodules $(\mathrm{P}<0.0001)$, greater nodule dry weight $(\mathrm{P}<0.0001)$ and biomass of plant $(\mathrm{P}<0.0001)$. The highest plant biomass in $2012(36.55 \mathrm{~g})$ and in $2013(36.95 \mathrm{~g})$ was obtained from inoculated plants. Inoculated plants also produced a significant numbers of flowers $(\mathrm{P}<0.0001)$ for both years. Root nodules were formed by both inoculated and uninoculated plants. But inoculated plant significantly formed $(\mathrm{P}<0.001)$ more nodules than the uninoculated control during the two cropping years. Similar finding were obtained after fields trials on cowpea in four agroecological zones of Cameroon: Soudano-sahelian, Guinea savannah, humid forest with monomodal rainfall, humid forest with bimodal rainfall (Ngakou 2007).

\subsection{Frequency of floral entomofauna of glycine max}

Among the 330 and 1844 visits of6 insect species recorded respectively on uninoculated flowers in 2012 and 2013, and378and2132 visits of 7 insect species recorded respectively on inoculated flowers of G. max, A. m. adansoniiwas ranked second as the most represented insect species the first year on both uninoculated and inoculated flowers. In the second year this bee was first on both uninoculated and inoculated flowers, with 1428 visits $(77.44 \%)$ on uninoculated flowers and 1608 visits $(75.42 \%)$ on inoculates ones (Table 3). Significant difference in the percentage of visits between flowers from uninoculated $\left(\chi^{2}=29.51 ; \mathrm{df}=1 ; \mathrm{P}<0.001\right)$ and inoculated $\left(\chi^{2}=35.74 ; \mathrm{df}=1 ; \mathrm{P}<0.001\right)$ plants were observed for the two years. Flowers of G. max were visited by Apidae (A. m. adansonii and Ceratina sp.), Formicidae (Camponotus acvapimensis), Halictidae (Lasioglossum sp.), Meloidae (Coryna sp.), Muscidae (Musca domestica) and Syrphidae (Epysyrphus balteatus). These insects were found to collect only nectar. Besides, Ceratina sp. was the most representative insect the first year against $A . \mathrm{m}$. adansonii the second year. For both years $A$. m. adansonii was the most representative insect on G. $\max$ flowers.

Table 2: Number of nodules, plant biomass and number of flowers of Glycine max as affected by Bradyrhizobium in 2012 and 2013

\begin{tabular}{llllll}
\hline Years & Treat & Nodules (per/plant) & Flowers (per/subplot) & Weight of dry nodules (g/plant) & Plant biomass (g/plant) \\
\hline \multirow{2}{*}{2012} & Uninoculated & $(10.61 \pm 0.86) \mathrm{a}$ & $(1299.14 \pm 230.268) \mathrm{a}$ & $(0.59 \pm 0.04) \mathrm{a}$ & $(15.38 \pm 1.19) \mathrm{a}$ \\
& Inoculated & $(23.6 \pm 0.86) \mathrm{b}$ & $(2182.94 \pm 263.80) \mathrm{b}$ & $(1.37 \pm 0.04) \mathrm{b}$ & $(36.55 \pm 1.19) \mathrm{b}$ \\
& P. value & $<0.0001$ & $<0.001$ & $<0.0001$ & $<0.0001$ \\
& Uninoculated & $(8.7 \pm 1.04) \mathrm{a}$ & $(1211.26 \pm 218.48) \mathrm{a}$ & $(0.48 \pm 0.05) \mathrm{a}$ & $(20.07 \pm 1.11) \mathrm{a}$ \\
\multirow{2}{*}{2013} & Inoculated & $(27.72 \pm 1.04) \mathrm{b}$ & $(2078.9 \pm 218.45) \mathrm{b}$ & $(1.50 \pm 0.05) \mathrm{b}$ & $(36.95 \pm 1.11) \mathrm{b}$ \\
& P. value & $<0.0001$ & $<0.001$ & $<0.0001$ & $<0.0001$ \\
\hline
\end{tabular}

Values in the same column followed by the same letter are not significantly different at $5 \%$ level. 
Table 3: Diversity of insects on Glycine max from uninoculated and inoculated flowers with Bradyrhizobium in 2012 and 2013 at Beka-Hossere, number and percentage of visits of different insects.

\begin{tabular}{|c|c|c|c|c|c|c|c|c|c|c|c|c|}
\hline \multirow{2}{*}{\multicolumn{3}{|c|}{ Insects }} & \multicolumn{4}{|c|}{2012} & \multicolumn{4}{|c|}{2013} & \multirow{2}{*}{\multicolumn{2}{|c|}{$\begin{array}{l}\text { Total } \\
2012 / 2013\end{array}$}} \\
\hline & & & \multicolumn{2}{|c|}{ Uninoculated } & \multicolumn{2}{|c|}{ Inoculated } & \multicolumn{2}{|c|}{ Uninoculated } & \multicolumn{2}{|c|}{ Inoculated } & & \\
\hline Order & Family & Genus, species, sub-species & $\mathrm{n}_{1}$ & $\mathrm{P}_{1}(\%)$ & $\mathrm{n}_{2}$ & $\mathrm{P}_{2}(\%)$ & $\mathrm{n}_{3}$ & $\mathrm{P}_{3}(\%)$ & $\mathrm{n}_{4}$ & $\mathrm{P}_{4}(\%)$ & nT & $\mathrm{PT}(\%)$ \\
\hline Coleoptera & Meloidae & Coryna sp. (eat flowers) & 17 & 5.17 & 15 & 3.97 & 22 & 1.19 & 10 & 0.47 & 64 & 1.36 \\
\hline \multirow[t]{6}{*}{ Diptera } & Muscidae & Musca domestica $(\mathrm{N})$ & 6 & 1.82 & 6 & 1.59 & 3 & 0.16 & 1 & 0.05 & 16 & 99.44 \\
\hline & Syrphidae & Epysyrphus balteatus $(\mathrm{N})$ & - & - & - & - & 4 & 0.22 & 6 & 0.28 & 10 & 0.34 \\
\hline & & Total Diptera & 6 & 1.82 & 6 & 1.59 & 7 & 0.38 & 7 & 0.33 & 26 & 0.56 \\
\hline & Apidae & Apis mellifera adansonii $(\mathrm{N})$ & 64 & 19.39 & 87 & 23.02 & 1428 & 77.44 & 1608 & 75.42 & 3187 & 68.04 \\
\hline & & Ceratina $\mathrm{sp} .(\mathrm{N})$ & 230 & 69.70 & 262 & 69.31 & 382 & 20.72 & 492 & 23.08 & 1366 & 29.16 \\
\hline & & Total Apidae & 294 & 89.09 & 349 & 92.33 & 1810 & 98.16 & 2100 & 98.50 & 4553 & 97.20 \\
\hline \multirow{5}{*}{ Hymenoptera } & Formicidae & $\begin{array}{l}\text { Camponotus acvapimensis } \\
\text { (N) }\end{array}$ & 7 & 2.12 & 4 & 1.06 & 5 & 0.27 & 3 & 0.14 & 19 & 0.40 \\
\hline & & Total Formicidae & 7 & 2.12 & 4 & 1.06 & 5 & 0.27 & 3 & 0.14 & 19 & 0.40 \\
\hline & Halictidae & Lasioglossum $\mathrm{sp} .(\mathrm{N})$ & 6 & 1.82 & 4 & 1.06 & - & - & 12 & 0.56 & 22 & 0.46 \\
\hline & & Total Halictidae & 6 & 1.82 & 4 & 1.06 & 0 & 0 & 12 & 0.56 & 22 & 0.46 \\
\hline & Total Hyme & ptera & 307 & 93.03 & 357 & 94.44 & 1815 & 98.42 & 2115 & 99.20 & 4594 & 98.07 \\
\hline Total & & & $\begin{array}{l}330 \\
(6)\end{array}$ & 100 & $\begin{array}{l}378 \\
(6)\end{array}$ & 100 & $\begin{array}{l}1844 \\
(7)\end{array}$ & 100 & $\begin{array}{l}2132 \\
(7)\end{array}$ & 100 & $\begin{array}{l}4684 \\
(7)\end{array}$ & 100 \\
\hline
\end{tabular}

$\mathrm{n}_{1}, \mathrm{n}_{2}, \mathrm{n}_{3}$ et $\mathrm{n}_{4}$ : number of visits on 30260 flowers in 22 days; sp.: undetermined species; $\mathrm{P}_{1}, \mathrm{P}_{2}, \mathrm{P}_{3}$ et $\mathrm{P}_{4}$ : visits percentages $\mathrm{P}_{1}=\left(\mathrm{n}_{1} / 330\right) * 100 ; \mathrm{P}_{2}=\left(\mathrm{n}_{2} / 378\right) * 100 ; \mathrm{P}_{3}=\left(\mathrm{n}_{3} / 1844\right)$ $* 100 ; \mathrm{P}_{4}=\left(\mathrm{n}_{4} / 2132\right) * 100$. Comparison of percentages visits: (Apis mellifera adansonii 2012/2013) $\chi^{2}=61.13 ; \mathrm{P}<0.001 ; \mathrm{N}$ : visitor collecting nectar.

\subsection{Activity of Apis mellifera adansonii on Glycine max flowers}

\subsubsection{Floral products harvested}

From our field observations and during the two flowering periods, A. $m$. adansonii foragers were found to intensively and regularly collect only nectar on flowers of both inoculated and uninoculated G. max plants as shown on Figure 3.

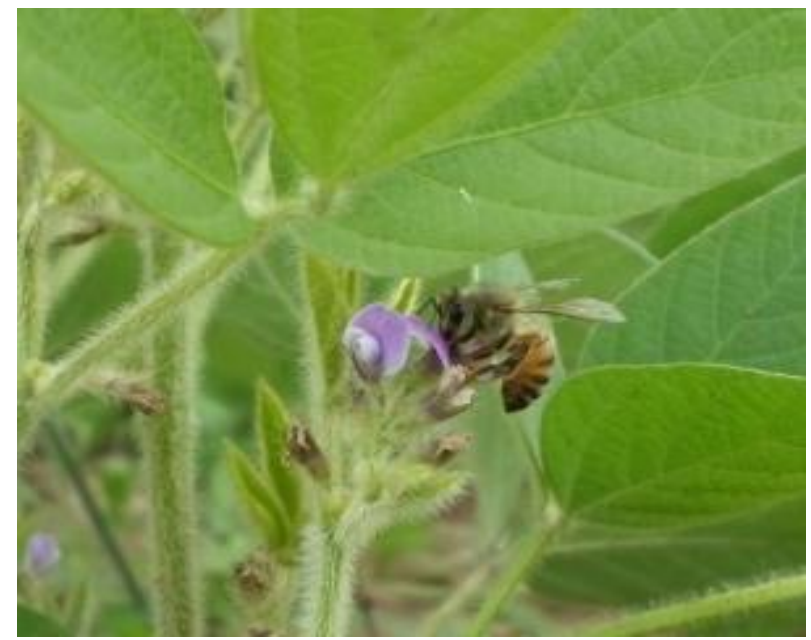

Fig. 3: Apis mellifera adansonii collecting nectar on a flower of Glycine $\max$ at Beka-Hossere

\subsubsection{Relationships between insect visits and flowering stages of the plant}

The number of visits was elevated when the number of opened flowers was higher on flowers of both uninoculated and inoculated plants (Figure 4). This was consistent up to day 9 (optimum), then decreased with time till days 21 . A positive and significant correlation was found between the numbers of opened flowers of uninoculated G. max plants and the number of $A$. m. adansonii ( $\mathrm{r}=0.88$; $\mathrm{ddl}=21 ; \mathrm{P}<0.001)$ in 2012 and 2013, as well as for flowers of inoculated plants in 2012 and 2013 ( $\mathrm{r}=0.87$; ddl=21; $\mathrm{P}<0.001$ ).

\subsubsection{Diurnal flower visits}

Apis mellifera adansonii foraged on G. max flowers daily and throughout the flowering period, with a peak of activity between 01.00 p.m. and 02.00 p.m. (Figure 5). This activity was influenced by temperature and hygrometry. The correlation between the number of $A . m$. adansonii visits and the temperature was positive and significant on uninoculated $G$. max flowers ( $\mathrm{r}=0.96$; $\mathrm{ddl}=3$; $\mathrm{P}<0.001)$ and inoculated ones $(\mathrm{r}=0.96 ; \mathrm{ddl}=3 ; \mathrm{P}<0.001)$ for the both years. Concerning the relative humidity, the correlation with the number of $A$. $m$. adansonii visits was negative and significant on uninoculated $(\mathrm{r}=-0.87 ; \mathrm{ddl}=3 ; \mathrm{P}<0.05)$ and inoculated $(\mathrm{r}=-$ 0.86 ; ddl $=3$; $\mathrm{P}<0.05$ ) flowers of this crop.

\subsubsection{Abundance of Apis mellifera adansonii}

In 2012, the highest mean number of $A$. m. adansonii simultaneous in activity was 1 per flower $(n=61 ; \mathrm{s}=0)$ and 3 per 1000 flowers $(n=260 ; s=1.32$; maxi $=10)$ on flowers of uninoculated plot and 1 per flowers $(n=90 ; s=0)$ and 3 per 1000 flowers $(n=251 ; s=1.63$; maxi=10) on flowers of inoculated subplot. In 2013, the corresponding values were $1(n=263 ; s=0)$ and 40 per 1000 flowers $(n=673 ; s=10.62 ; \operatorname{maxi}=92)$ on flowers of uninoculated subplot and 1 per flowers $(n=182 ; s=0)$ and 3 per 1000 flowers $(n=266$; $\mathrm{s}=14.17$; maxi $=80$ ) on flowers of inoculated subplot. 


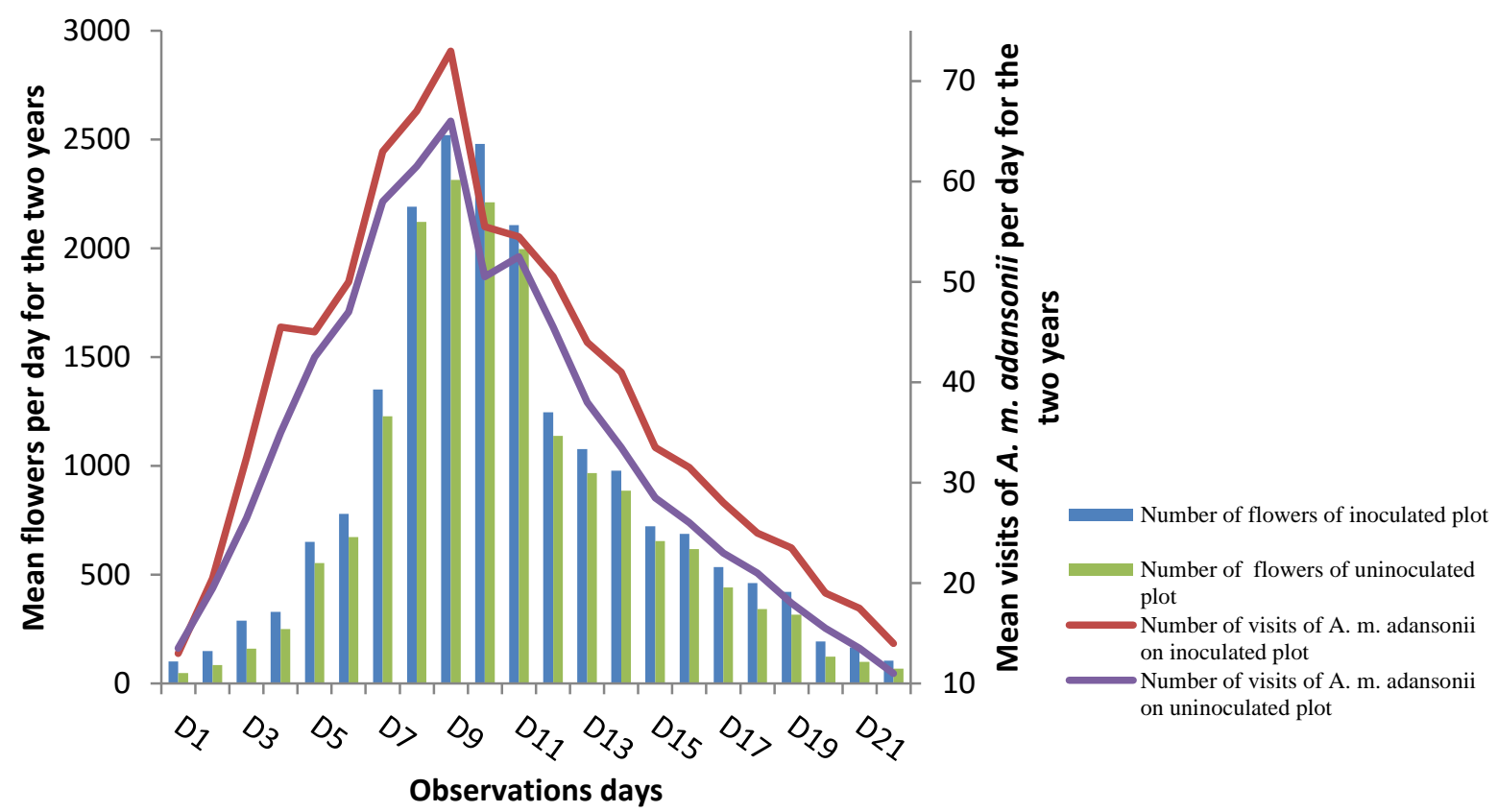

Fig. 4: Variations of the number of Glycine max opened flowers and the number of Apis mellifera adansonii visits with observation days in 2012 and 2013 at Beka-Hossere.

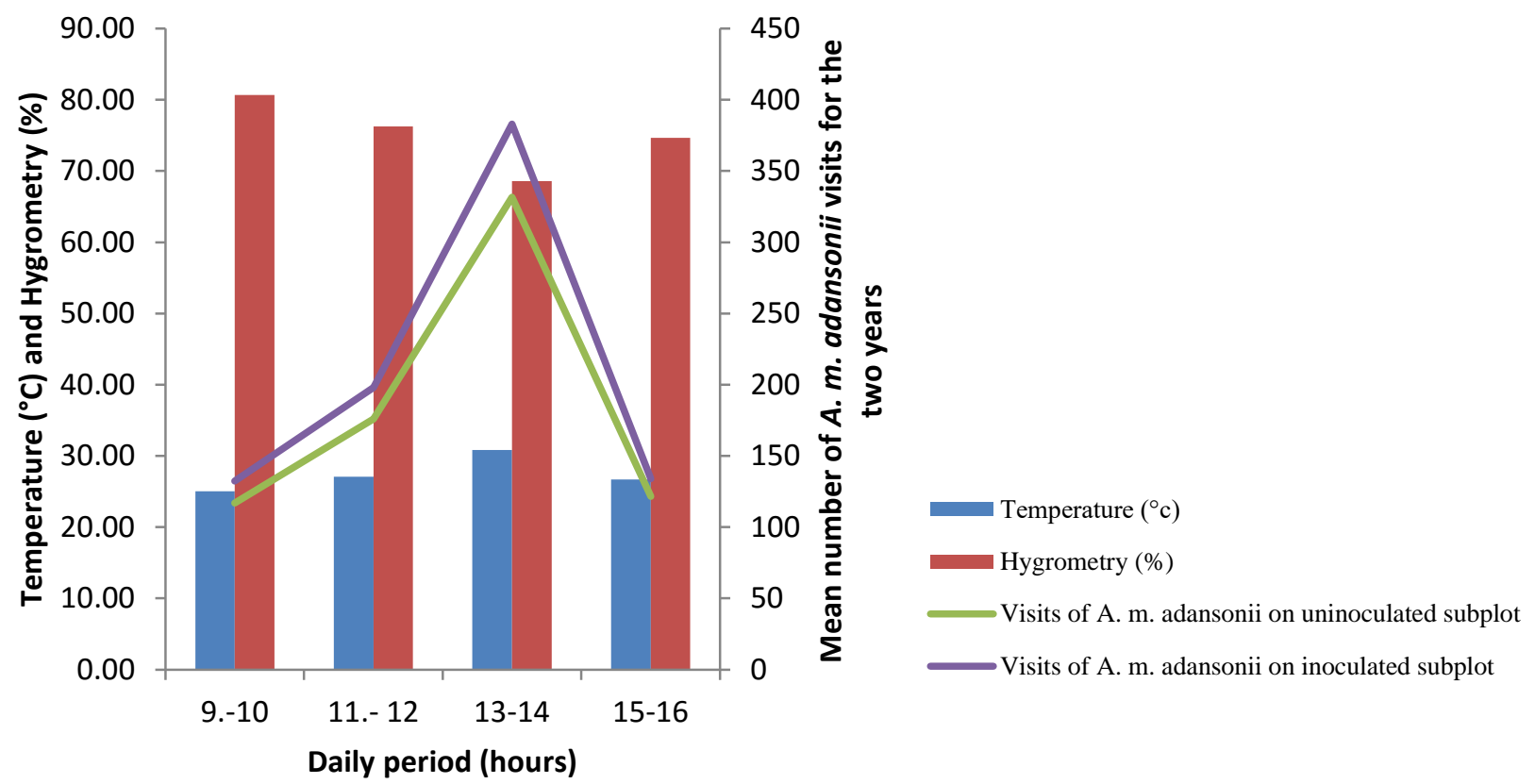

Fig. 6: Daily distribution of Apis mellifera adansonii visits on Glycine max flowers over 22 Days in 2012 and 2013 as influenced by mean temperature and mean humidity at Beka-Hossere.

\subsubsection{Duration of Apis mellifera adansonii visits per flower}

In 2012, the mean duration of a flower visit was $7.26 \mathrm{sec}(n=346$; $\mathrm{s}=4.18 ; \max =42 \mathrm{sec}$ ) on flowers of uninoculated subplot and 7.42 $\sec (n=240 ; s=4.47 ; \max =21 \mathrm{sec})$ on flowers of inoculated subplot, whereas in 2013, the visit lasted for $7.73 \mathrm{sec}(\mathrm{n}=613$; $\mathrm{s}=2.58$; $\max =12 \mathrm{sec})$ on flowers of uninoculated subplot and $8.79 \mathrm{sec}$ $(\mathrm{n}=634 ; \mathrm{s}=4.26 ; \max =21 \mathrm{sec})$ on flowers of inoculated subplot. The difference was highly significant $(\mathrm{t}=29.3 ; \mathrm{df}=957 ; \mathrm{P}<0.001)$ between the mean duration of visits per flowers of uninoculated subplot and that flowers from inoculated subplot $(\mathrm{t}=55.16$; $\mathrm{df}=872 ; \mathrm{P}<0.001)$. For the two cumulative years, the mean duration of a flower visit was $7.49 \mathrm{sec}$ for uninoculated subplot and $8.10 \mathrm{sec}$ for the inoculated subplot.

\subsubsection{Foraging speed of Apis mellifera adansonii on Glycine $\max$ flowers}

In Glycine max field, A. m. adansonii visited between 3.24 and 33 flowers/min on uninoculated subplot and on inoculated subplot between 1.38 and 30 flowers/min in 2012. In 2013, A. m. adansonii visited between 1.85 and 45 flowers/min on uninoculated subplot and 8.18 and 30 flowers/min on inoculated subplot. The mean foraging speed was 10.66 flowers/min $(n=182, \mathrm{~s}=5.29)$ on uninoculated subplot and 9.41 flowers/min $(n=175 ; s=5.99)$ on inoculated subplot in 2012. In 2013, the mean foraging speed was 14.90 flowers/min $(n=486 ; s=9.24)$ on uninoculated subplot and 17.10 flowers/min $(n=355, s=6.02)$ on inoculated subplot. The difference between these means was highly significant $(\mathrm{t}=67.12 ; \mathrm{P}<0.001)$ for uninoculated subplot or inoculated ones $(\mathrm{t}=149.69 ; \mathrm{P}<0.001)$. For the two cumulated years, the mean foraging speed was 12.78 
flowers/min for uninoculated plot and 13.25 flowers/min for inoculated ones.

\subsubsection{Influence of neighboring flora}

During the observation period, flowers of many other plant species growing in the study area were visited by A. m. adansonii for either nectar (ne) or pollen (po). Amongst those plant species were Arachis hypogea (Fabaceae, ne), Bidens pilosa (Asteraceae, ne and po), Cucumeropsis manii (Cucurbitaceae, ne), Cucumis melo (Cucurbitaceae, ne and po), Hypomea batatas (Convolvulaceae, ne), Phaseolus coccineus (Fabaceae, ne and po), Phaseolus vulgaris (Fabaceae, ne and po), Senna mimosoides (Mimosaceae, ne and po), Vigna unguiculata (Fabaceae, ne and po) and Zea mays (Poaceae, po). During the entire observation period, A. m. adansonii foragers on G. max flowers were not observed moving to a neighboring plant of a different species and vice versa. That bee's foragers were regularly interrupted by other foragers or by other bees collecting G. max floral products such as Ceratina sp. (ne).

\subsubsection{Apicultural value of Glycine max}

During G. max flowering period, a well elaborated activity of $A$ $m$. adansonii was registered on its flowers. In particular, there were good nectar harvest and workers faithfulness to its flowers. These data point out the good attractiveness of $G$. max nectar to $A$. $m$. adansonii. From this, it appears that our studied plant could be classified in as a highly nectariferous bee plant.

\subsubsection{Impact of Apis mellifera adansonii on pollination, pod/set and seed yields of Glycine max}

Apis mellifera adansonii foragers were always in contact with the stigma and the anthers of $G$. $\max (100 \%$ for all visits). Consequently this bee increased possibilities of the pollination of G. max flowers.

Table 4: Variation of yield components between treatments as influenced by protection of Glycine max flowers from Apis mellifera adansonii in 2012 and 2013 at Beka-Hossere.

\begin{tabular}{|c|c|c|c|c|c|c|c|c|c|}
\hline Year & Treatments & Flowers & Pod & $\begin{array}{l}\text { Fruiting } \\
\text { rate }(\%)\end{array}$ & $\begin{array}{l}\text { Seeds/ } \\
\text { Mean }\end{array}$ & $\mathrm{SD}$ & $\begin{array}{l}\text { Total } \\
\text { seeds }\end{array}$ & $\begin{array}{l}\text { Normal } \\
\text { seeds }\end{array}$ & $\begin{array}{l}\text { \%Normal } \\
\text { seeds }\end{array}$ \\
\hline \multirow{3}{*}{2012} & 1 (Unlimited visits) & 14247 & 10752 & 75.46 & 1.89 & 0.70 & 27405 & 24132 & 88.05 \\
\hline & 2 (Bagged flowers) & 15007 & 9987 & 66.54 & 0.76 & 0.47 & 12975 & 8867 & 68.33 \\
\hline & 3 (A. m. adansonii visits on flowers) & 51 & 51 & 100 & 3.17 & 0.68 & 170 & 164 & 96.47 \\
\hline \multirow{3}{*}{2013} & 4 (Unlimited visits) & 20352 & 19547 & 96.04 & 2.14 & 0.49 & 36409 & 33883 & 93.06 \\
\hline & 5 (Bagged flowers) & 18867 & 11645 & 61.72 & 1.05 & 0.6 & 17842 & 11723 & 65.69 \\
\hline & 6 (A. m. adansonii visits on flowers) & 120 & 120 & 100 & 3.52 & 0.61 & 478 & 469 & 98.11 \\
\hline
\end{tabular}

\section{Cumulative impact of flowering insects and Bradyrhizobium on the pollination, pod and seed yields of Glycine max}

The comparison of the fruiting rate (table 5) shows that the differences observed were significant between treatments 2 and 7 $\left(\chi^{2}=10.81 ; \mathrm{df}=1 ; \mathrm{P}<0.01\right)$, and treatment 5 and $8\left(\chi^{2}=20.51 ; \mathrm{df}=1\right.$; $\mathrm{P}<0.001)$. Therefore, in 2012, the fruiting rate of flowers inoculated and opened to insects (treatment 7) was higher than that of protected flowers (treatment 2) whereas in 2013; the fruiting rate of inoculated flowers opened to insects (treatment 8) was higher than that of flowers (treatment 5) protected from insects visits.

The number of seeds per pod from flowers of inoculated flowers and opened to insects (treatment 7) was significantly higher $(\mathrm{t}=2887.66 ; \mathrm{P}<0,001)$ than that of flowers protected from insects visits (treatment 2). Similarly, in 2013 the number of seeds per pod of inoculated flowers opened to insects was significantly higher $(\mathrm{t}=5070.84 ; \mathrm{P}<0,001)$ than that of flowers protected from insects visits.
The comparison of the fruiting rate (table 4) shows that differences observed were highly significant between treatment 2 and 3 $\left(\chi^{2}=40.18 ; \mathrm{df}=1 ; \mathrm{P}<0,001\right)$, as well as treatment 5 and $6\left(\chi^{2}=47.34\right.$; $\mathrm{df}=1 ; \mathrm{P}<0,001)$. Hence, the fruiting rate of unprotected flowers opened exclusively to A. m. adansonii visits (treatment $3 ; 2012$ and treatment $6 ; 2013$ ) was higher than that of bagged flowers (treatment 2; 2012 and treatment 5; 2013)

The comparison of the mean number of seeds per pod showed that the differences were highly significant between treatment 2 and 3 $(\mathrm{t}=265.90 ; \mathrm{P}<0,001)$ and treatments 5 and $6(\mathrm{t}=488.83 ; \mathrm{P}<0,001)$. As the matter of fact, in 2012, seed yield per pod of flowers protected and visited by A. m. adansonii (treatment 3) was higher than that of flowers protected from insects (treatment 2). In 2013, seed yield per fruit of flowers protected and visited exclusively by A. $m$. adansonii (treatment 6) was greater than that of flowers protected from insect visits (treatment 5). The comparison of the percentages of normal seeds shows that the differences were highly significant between treatment 2 and $3 \quad\left(\chi^{2}=27.30 ; \mathrm{df}=1\right.$; $\mathrm{P}<0,001)$, then treatments 5 and $6\left(\chi^{2}=35.45 ; \mathrm{df}=1 ; \mathrm{P}<0,001\right)$. Thus, the percentages of normal seeds of flowers protected and visited exclusively by $A$. $m$. adansonii (treatment 3 ) was higher than those protected from insects (treatment 2).

The fruiting rate due to A. $m$. adansonii activity was $33.46 \%$ in 2012 and $38.28 \%$ in 2013. For the two years of study, the fruiting rate percentage attributed to $A$. $m$. adansonii was $35.87 \%$. The number of seeds per pod attributed to this bee activity was $76.02 \%$ in 2012 and $70.17 \%$ in 2013. For the two years of study, the proportion of seeds per pod due to A. m. adansonii was $73.09 \%$. The number of normal seeds due to $A$. $m$. adansonii was $29.16 \%$ in 2012 and $33.04 \%$ in 2013. For the two years of study, the number of normal seeds per pod attributed to $A$. $m$. adansonii activity was $31.1 \%$. In short, the influence of $A$. m. adansonii on pod and seeds yields on $G$. $\max$ was positive and significant.

The comparison of the percentages of normal seeds shows that the differences were highly significant between treatments 2 and 7 $\left(\chi^{2}=17.02 ; \mathrm{df}=1 ; \mathrm{P}<0,001\right)$, and treatments 5 and $8\left(\chi^{2}=23.60\right.$; $\mathrm{df}=1 ; \mathrm{P}<0,001)$. In 2012, the percentage of normal seeds of flowers of inoculated plots and opened to insects (treatment 7) was higher than that of flowers protected from insect visits (treatment 2 ), while in 2013, the percentage of normal seeds of flowers of inoculated plots and opened to insects (treatment 8) was higher than that of flowers protected from insects visits (treatment 5).

The fruiting rate due to cumulative effects of flowering insects and Bradyrhizobium activity was $28.78 \%$ in 2012 and $35.54 \%$ in 2013. For the two years of study, the fruiting rate $(\%)$ influenced by both flowering insects and Bradyrhizobium was $32.16 \%$.

The cumulative effect of flowering insects and Bradyrhizobium on the number of seeds per pod was $31.46 \%$ in 2012 and $34.28 \%$ in 2013. For the two years of study, the percentage of the number of seeds per pod due to flowering insects and Bradyrhizobium was $32.87 \%$.

The number of normal seeds due to cumulative effects of flowering insects and Bradyrhizobium activity was $75.94 \%$ in 2012 and $70.59 \%$ in 2013. For the two years of study, the percentage of the 
number of normal seeds per pod attributed to cumulative effects of flowering insects and Bradyrhizobium activity was $73.26 \%$. Hence, the cumulative influence of flowering insects and Brady- rhizobium on pod and seeds yields of $G$. max was positive and significant.

Table 5: Variation of yield components between treatments of Glycine max as influenced by Bradyrhizobium in 2012 and 2013 at Beka-Hossere.

\begin{tabular}{|c|c|c|c|c|c|c|c|c|c|}
\hline Year & Treatments & Flowers & Pod & $\begin{array}{l}\text { Fruiting } \\
\text { rate }(\%)\end{array}$ & $\begin{array}{l}\text { Seeds/1 } \\
\text { Mean }\end{array}$ & SD & $\begin{array}{l}\text { Total } \\
\text { seeds }\end{array}$ & $\begin{array}{l}\text { Normal } \\
\text { seeds }\end{array}$ & $\begin{array}{l}\text { \%Normal } \\
\text { seeds }\end{array}$ \\
\hline \multirow[t]{2}{*}{2012} & 2 (Bagged flowers) & 15007 & 9987 & 66.54 & 0.76 & 0.47 & 12975 & 8867 & 68.33 \\
\hline & 7 (Inoculated flowers open to insects) & 14978 & 12924 & 86.28 & 1.38 & 1.22 & 19583 & 17957 & 91.69 \\
\hline \multirow[t]{2}{*}{2013} & 5 (Bagged flowers) & 18867 & 11645 & 61.72 & 1.05 & 0.6 & 17842 & 11723 & 65.69 \\
\hline & 8 (Inoculated flowers open to insects) & 19986 & 17842 & 89.27 & 1.47 & 0.70 & 27824 & 25989 & 93.40 \\
\hline
\end{tabular}

\section{Discussion}

Rhizobia including Rhizobium and Bradyrhizobium are the best know as biological nitrogen fixers in root nodules of legumes (Kiers et al. 2003, Denison \& Kiers 2004, Ngakou et al. 2007). In the Guinea-savannah zone of Cameroon, the number of nodule formed by cowpea was reported to be low in the absence of inoculum (Ngakou 2007), with nodules starting to degenerate as from 45 days after planting. Successful nodulation of leguminous crops by Rhizobium largely depends on the presence of a specific and compatible strain in the soil for a particular legume (Tamiru et al. 2012). The positive correlation between nodules and plant dry weight was in accordance with findings of others authors (Thiagarajan et al. 1992, Hungria et al. 2001, Kengni et al. 2015). There was a significant correlation between nodulation and the plant biomass, supporting the improved nitrogen fixation potential of the host grain legume that usually lead to increase soil fertility (Ngakou et al. 2008, Kengni et al. 2015).

During the first year, Apis mellifera adansonii was not the preponderant insect on Glycine max flowers, but in the second year and with the introduction of the hive in the farm, A. m. adansonii came first.Cumulatively, this bee was the most frequent insect and visited soybean flowers intensively. These results confirm those already reported by Tchuenguem\&Dounia (2014), who revealed A. $m$. adansonii as the most frequent insect on flowers of the same plant in Maroua. This shows that plant possess specific food ressources available to insects through flowers. This bee has been reported as the main floral visitor of this Fabaceae in USA (Rortais et al. 2005) and Brazil (Milfont et al. 2013, Chiari et al. 2005). The present work shows that honey bee visited soybean flowers only for nectar collection. This result is in accordance with those of Tchuenguem\&Dounia (2014) in Maroua where this bee collected exclusively nectar on soybean flowers. The significant difference between the percentages of A. m. adansonii visits for the two studied years could be attributed to the installation of a hive the second year in the experimental site. The peak of activity of $A . m$. adansonii on G. max flowers was at between 01.00 p.m. and 02.00 p.m., which corresponds probably to the period of highest availability of nectar on G. max flowers. The positive and highly significant correlation between the number of $G$. $\max$ flowers and the number of $A . m$. adansonii visits indicates the attractiveness of $G$. $\max$ to nectar with respect to this bee. The significant difference observed between the duration of visits in 2012 and 2013 could be attributed to the availability of nectar, the floral morphology of this crop or the variation in the diversity of flowering insects from one year to another.

During our investigations, the interruption of visits by other insects or the same honey bee reduced the duration of A. m. adansonii visits. This result confirms other findings reported by Tchuenguem\&Dounia (2014) on G. max in Maroua-Cameroon. The present study shows that during one forage trip, an individual bee foraging on a given plant species scarcely visited another plant species, confirming the flower constancy of $A$. $m$. adansonii to flower of soybean (Basualdo et al. 2000). Flower constancy is an important aspect in the management of pollination and this shows that $A$. $m$. adansonii can provides the advantages to the management of G. max. During the rainy season 2012, 2013 in Ngaoun- dere, A. m. adansonii intensely and regularly harvested nectar on the flowers of G. $\max$ during flowering periods. This could be attributed to the needs of colonies during the flowering period. It indicates that $A$. $m$. adansonii can increased soybean pollination. During the collection of nectar, A. m. adansonii foragers, though their weight shook G. $\max$ flowers. This movement played a positive role in liberation of pollen by anthers for the optimal occupation of the stigma. This phenomenon was also reported by Ahrent\&Caviness (1994), Rortais et al. 2005 and Tchuenguem\&Dounia (2014) on G. max. Apis mellifera adansonii foragers also affected self-pollination and cross-pollination of soybean flowers. The positive and significant contribution of A. m. adansonii in fruiting rate, seed yields and percentage of normal seed of G. $\max$ is justified by its action on pollination. Similar results were obtained in Maroua (Tchuenguem\&Dounia 2014) on $G$. max; showing that self-pollination of this plant produced little seeds per pod in the absence of efficient pollinators. The higher percentage of seeds number and normal seeds in the treatment visiting exclusively by $A$. $m$. adansonii compared to treatment bagged, indicate that insect visits were effective in increasing cross-pollination or self-pollination. Our results confirm those of Rortais et al. (2005), Milfont et al. (2013) and Tchuenguem\&Dounia (2014), who revealed that $G$. max flowers set little pods in the absence of pollinator's insects. In our experiment, the uses of both flowering insects and Bradyrhizobium highly improved the seed and pod yields of G. max, as flowering insects have facilitated the liberation of pollen from anthers for optimal occupation of the stigma, thus increasing pollination (Tchuenguem\&Dounia 2014); Bradyrhizobium contribuated to the improvement of nitrogen fixation potential of the host legume that led to increased plant growth and yield (Ngakou et al. 2007). Same results was obtain by Kengni et al. 2015 who revealed that the use of both flowering insect and Rhizobium highly improved the seeds and pods yields on Vigna unguiculata in Ngaoundere. Investment in $A$. $m$. adansonii management and inoculation with Bradyrhizobium may provides high returns to investment on this valuable crop.

\section{Conclusion}

From our study, G. $\max$ is a plant species that highly benefits from pollination by insects, of which $A$. $m$. adansonii is the most important and exclusively harvest nectar. The comparison of the pod and seed sets of unprotected flowers with those of flowers exclusively visited by $A$. $m$. adansonii underscores the value of this bee in increasing pod and seed yields, as well as improving seed quality. Furthermore, the comparison of pod and seeds set of uninoculated and bagged flowers with those of flowers inoculated with Bradyrhizobium and visited by insects indicates the value of cumulative activity of insects and Bradyrhizobium in increasing pod and seeds yields. Our results suggest that sowing G. max seeds with Bradyrhizobium and the installation of $A$. $m$. adansonii hives close to this crop fields could be encouraged to significantly improve the pods and seeds production of this important legume. 


\section{References}

[1] Ahrent DK \& Caviness CE (1994) Natural cross-pollination of twelve soybean cultivars in Arkansas. Crop Science 34(2): 376378.

http://dx.doi.org/10.2135/cropsci1994.0011183X003400020013x.

[2] Alghamdi SS (2004) Yield stability of some soybean genotypes across diverse environments. Pakistan Journal of Biological Sciences 7(12): 2109-2114. http://dx.doi.org/10.3923/pjbs.2004.2109.2114.

[3] Basualdo M, Bedascarrasbure E \& De Jong D (2000) Africanized honey bees (Hymenoptera: Apidae) have a greater fidelity to sunflowers than European bees. Journal of EconomicEntomology 92(2): 304-307. http://dx.doi.org/10.1603/0022-0493-93.2.304.

[4] Boyeldieu J (1991) Produire des grains oléagineux et proteagineux. Ed. tec et Doc/Lavoisier Col. Agriculture d'aujourd'hui. pp. 115152.

[5] Chiari WC, Arnaut de Toledo V de A, Ruvolo-Takasusuki MCC, Braz de Oliveira AJ, Sakaguti1 ES, Attencia VM, Costa FM \& Mitsui M H (2005a) Pollination of Soybean (Glycine max L. Merril) by Honeybees (Apis mellifera L.). Brazilian Archives of Biology and Technology 48(1): 31-36. http://dx.doi.org/10.1590/S151689132005000100005.

[6] Denison RF \& Kiers ET (2004) Why are most rhizobia beneficial to their plant hosts, 1088 rather than parasitic. Microbes Infection 6: 1235-1239 http://dx.doi.org/10.1016/j.micinf.2004.08.005.

[7] Diers BW, Keim P, Fehr WR \& Shoemaker FC (1992) RFLP analysis of Soybean seed protein and oil content. Theorical and Applied Genetics 83: 608-612. http://dx.doi.org/10.1007/bf00226905.

[8] Douka C \& Tchuenguem FF-N (2013) Foraging and pollination behavior of Apis mellifera adansonii L. (Hymenoptera, Apidae) on Phaseolus vulgaris (Fabaceae) flowers at Maroua (Cameroon). International Research Journal of Plant Science 4(2): 45-54.

[9] Gallais A. \& Bannerot H (1992) Amélioration des espèces végétales cultivées. INRA, Paris. $768 \mathrm{p}$

[10] Hungria M, Campo RJ \& Chueire LMO (2001) Symbiotic effectiveness of fast-growing rhizobia strains isolated from soybean nodules in Brazil. Biology and Fertility of Soils 33: 387-394 http://dx.doi.org/10.1007/s003740100338

[11] Hymowitz T. \& Harlan JR (1983) Introduction of soybean to North America by Samuel Bowen in 1765. Economic Botany 37(4): 371379. http://dx.doi.org/10.1007/BF02904196.

[12] Ikeogu UN \& Nwofia GE (2013) Yield parameters and stability of soybean (Glycine $\max$ L. Merill) as influenced by phosphorus fertilizer rates in two ultisols. Journal of Plant Breeding and Crop Science 5(4): 54-63. http://dx.doi.org/10.5897/JPBCS12.014.

[13] Kengni BS, Tchuenguem FF-N \& Ngakou a (2015) Pollination and yield attributes of (cowpea) Vigna unguiculataL. Walp. (Fabaceae) as influenced by the foraging activity of Xylocopa olivacea Fabricius (Hymenoptera: Apidae) and inoculation with Rhizobium in Ngaoundere, Cameroon. International Journal of Agronomy and Agricultural Research 6(2): 62-76.

[14] Kiers ET, Rousseau RA, West SA \& Denison RF (2003) Host sanctions and the legume-Rhizobium mutualism. Nature 425: 7881.http://dx.doi.org/10.1038/nature01931.

[15] Kingha BMT, Tchuenguem FF-N, Ngakou A \& Brückner D (2012) Foraging and pollination activities of Xylocopa olivacea (Hymenoptera, Apidae) on Phaseolus vulgaris (Fabaceae) flowers at Dang (Ngaoundere-Cameroon). Journal of Agricultural Extension and Rural Development 4: 330-339.

[16] Milfont MO, Rocha EEM, Lima AON \& Freitas BM (2013) Higher soybean production using honeybee and wild pollinators, a sustainable alternative to pesticides and autopollination. Environmental and Chemestry Letters 11(4): 335-341. http://dx.doi.org/10.1007/s10311-013-03.

[17] MINADER / DESA (2012) Annuaire des Statistiques du secteur Agricole, Campagnes 2009 \& 2010. Direction des Enquêtes et des Statistiques Agricoles. AGRI-STAT $\mathrm{N}^{\circ} 17: 123 \mathrm{p}$.

[18] Ngakou A, Nwaga D, Ntonifor NN, Tamo M, Nebane CLN \& Parh IA (2007) Contribution of Arbuscular Mycorrhizal Fungi (AMF), rhizobia and Metarhizium anisopliae to cowpea production in Cameroon. International Journal of Agricultural Research 2(9): 754-764.http://dx.doi.org/10.3923/ijar.2007.754.764.

[19] Ngakou A, Megueni C, Makalao M, Nwaga D, Taine J \& Ndjouenkeu R (2008) Changes in the physico-chemical properties of soil and harvested soybean seeds in response to soil solarization and bradyrhizobial inoculation. Archives of Agronomy and Soil Science 54(2): 189-202. http://dx.doi.org/10.1080/03650340701793579.

[20] Ngakou A, Megueni C, Ousseini H. \& Massai A (2009) Study on the isolation and characterization of rhizobia strains as biofertilizer tools or growth improvement of four grain legumes in Cameroon. International Journal of Biological and Chemical Sciences 3(5): 1078-1089.

[21] Ormeño-Orrillo E, Menna P, Almeida LGP, Ollero FJ, Nicolás MF, Rodrigues EP, Nakatami AS, Batista JSS, Chueire LMO, Souza RC, Vasconcelos ATR, Megías M, Hungria M \& MartínezRomero E (2012) Genomic basis of broad host range and environmental adaptability of Rhizobium tropici CIAT 899 and Rhizobium sp. PRF 81 which are used in inoculants for common bean (Phaseolus vulgaris L.). BMC Genomics 13: 735 http://dx.doi.org/10.1186/1471-2164-13-735.

[22] Rortais A, Arnold G, Halm M-P \& Touet-Briens F (2005) Modes of honeybees exposure to systemic insecticides: estimated amounts of contamined pollen and nectar consumed by different categories of bees. Apidologie 36(1): 71-83

http://dx.doi.org/10.1051/apido:2004071.

[23] Summers MC \& Mondor EB (2011) Rhizobium alter inducible defenses in broad bean, Vicia faba. Open journal of Ecology 1(3): 52-62.

[24] Tamiru S, Lalit MP \& Tsige A (2012) Effects of inoculation by Bradyrhizobium japonicum strains on nodulation, nitrogen fixation, and yield of soybean (Glycine max L. Merill) varieties on nitisols of Bako, Western Ethiopia. International Scholarly Research Network (2012): 1-8.

[25] Tchuenguem FF-N, Ngakou A \& Kengni BS, (2009b) Pollination and yield responses of cowpea (Vigna unguiculata L. Walp.) to the foraging activity of Apis mellifera adansonii (Hymenoptera: Apidae) at Ngaoundéré (Cameroon). African Journal of Biotechnology 8: 1988-1996

[26] Tchuenguem FF-N \& Dounia (2014) Foraging and pollination behavior of Apis mellifera adansonii (Hymenoptera: Apidae) on Glycine max L. flowers at Maroua. Journal of Research in Biology 4(1): 1209-1219.

[27] Tchuenguem FF-N, Djongwangwé D, Messi J \& Brückner D, (2007) Exploitation des fleurs de Entada africana, Eucalalyptus camadulensis, Psidium guajava et Trichilia emetica par Apis mellifera adansonii à Dang (Ngaoundéré-Cameroun). Cameroon Journal of Experimental Biology 3: 50-60.

[28] Thiagarajan TR \& Ahamad MH, (1993) Influence of a vesiculararbuscular mycorrhizal funguson on the competition ability of Bradyrhizobium spp. for nodulation of cowpea (Vigna unguiculata L. Walp.) in non-sterilized soil. Biology and Fertility of Soils15: 294-296.http://dx.doi.org/10.1007/BF00337215.

[29] Tien HH, Hien TM, Son MT \& Herridge D (2002) Rhizobial Inoculation and $\mathrm{N}_{2}$ fixation of soybean and mungbean in the eastern region of South Vietnam. In "inoculants and nitrogen fixation of legumes in Vietnam". Edited by D. Herridge. ACIAR Proceedings $109^{\mathrm{e}}$. 